\title{
Didactic Innovations through YouTube and Gigapan: Teachers' Perceptions in Classrooms in Southern Chile
}

\author{
Luis Cárcamo-Ulloa, Paula Flores-Aguilar, Juan Domingo Ramírez \\ Department of Social Communication, Universidad Austral de Chile, Valdivia, Chile \\ Email: Icarcamo@uach.cl
}

Received 4 April 2014; revised 30 April 2014; accepted 19 May 2014

Copyright (C) 2014 by authors and Scientific Research Publishing Inc.

This work is licensed under the Creative Commons Attribution International License (CC BY).

http://creativecommons.org/licenses/by/4.0/

\begin{abstract}
There are few experiences using Social Web (or Web 2.0) for collaborative learning in public schools of Chile; therefore this is an emerging challenge for professors of the techno-pedagogical units. This article describes innovation strategies that incorporate Social Web tools in the formal education process in Chile. Using scholar ethnographies we describe 26 different classrooms experiences (between 2010 and 2012) using YouTube (for secondary schools) and GigaPan (for primary schools) to teach history and language contents, respectively. The main conclusions show the motivational drive that the Social Web provides in the regular classroom setting. The teachers valued positively the result of the students work groups, and the exchange of experiences among groups.
\end{abstract}

Keywords

Collaborative Work, Educational Innovation, Web 2.0, Didactics with IT, Chile

\section{Introduction}

The relevance of the information and communications technologies (ICTs) in teaching-learning processes is a matter of discussion. Evidently, a learning process is complex enough to think that simple implementation of technology can automatically induce more and better learning. Moreover the adoption of Web 2.0 in education remains modest compared with its uses in the daily life (Crook, 2012). However, it cannot be denied the motivational value that currently dialogical tools brings to children and young people (Cladellas, Cárcamo, \& Castelló, 2011). Also, experiences with mobile technologies have been promoted as achieving an impact in the classroom (Wang, Shen, Novak, \& Pan, 2009).

How to cite this paper: Cárcamo-Ulloa, L., Flores-Aguilar, P., \& Ramírez, J. D. (2014). Didactic Innovations through YouTube and Gigapan: Teachers' Perceptions in Classrooms in Southern Chile. Creative Education, 5, 1071-1079. 
Specifically, the use of Social Web applications in teaching can already be found in relevant research about educational uses of Facebook, in university teaching contexts (Pimmer, Linxen, \& Gröhbiel, 2012), experiences of collaborative work between university and secondary students (Florentin, Satisteguí, Herrando, \& Tobajas, 2011), and meta investigations about micro-blogging tools such as Twitter, with educational purposes (Gao, Luo, \& Zhang, 2012) that all coincide in concluding that these tools encourage participation, commitment, reflexive thinking and collaborative learning in different learning environments. Charles Crook recognizes four potential contributions of Web 2.0 in education: "1) Inquiry. Web 2.0 creates new structures for organizing data: new sources to refer to, multiple forms of authority, and new tools to interrogate this rich space of information. 2) Literacies. Widely accessible digital media offer new modes of representation and offer tools that invite developing fluency in the related modes of self-expression. 3) Collaboration. The concept of joint activity implied by this term is extended by the range of loosely coupled co-ordinations that can exist within structures of large scale network participation, although Web 2.0 also offers tools for convening and managing more intimate and intense collaborative activity. 4) Publication. Web 2.0 structures can support users in creating original material for dissemination, providing for that both tools and an audience” (Crook, 2012: p. 64).

Studies exist that investigate the use of YouTube and social web platforms for education mediation. For example, Giannakos \& Vlamos (2013) investigated the use of YouTube and LearningTube as webcast tools that supported video for professional formation or as educational devices. Schoen \& Stevenson (2010) worked the use of Gigapan in formal and informal environmental education. Other academic instances exist (Ivala, Gachago, Condy, \& Chigona, 2013) with results that support the notion that the production of digital stories reinforces the commitment of the students and their studies, favoring high levels of reflection about the topics investigated, as well as a profound understanding of the material. According to Lint (2013), the means of communication and social networks have been seen as a problem for schools, but it could also be a solution if the social interactions are increased about academic or scholarly topics.

With respect to the incorporation of the ITCs, the plans and programs of the Ministry of Education in Chile contemplates in an explicit manner within the Transversal Objectives of the Curricular Framework (Mineduc, 2011), an educational ITC integrated into classwork, promoting that the tasks of the students also includes the use of ITC for: a) the search for information, b) data processing, c) the presentation of reports, d) information exchange and e) the correct recognition of the origin of the information.

If the Transverse Objectives do not propose a radical shift in the Chilean school system towards collaborative measures, it is possible to say that the programs do contemplate the inclusion of technologies in the teaching-learning process. The reality of the Chilean classroom shows that the ITCs orientations appear quite dissociated from learning due to the lack of integrating, didactic proposals. Moreover, many times these proposals, do not consider the student's previous knowledge. In other words, these proposals does not consider that students are digital natives (Mardones \& Cárcamo, 2013). If 20 years ago the incorporation of ITCs invited the incorporation the use of word processing to elaborate a work order, or a spreadsheet to graph statistical data, today, the pedagogical innovation should be installed in learning communities for the creativity and the communication. The objectives of to assembly Web 2.0 and education should be value, comment and share educative information inter-classrooms. "In order to achieve that members of a determined community increase their knowledge in an optimum manner, the contents that the members receive should be labeled, valued and commented according to their needs” (Astigarraga, Azpillaga, Fernández, \& Naberan, 2011: p. 543).

Additionally, for educators as well as for ITC professionals in Social Web, continual changes are produced at a level of technological tools that require that one does not stay anchored in one system or resource, and, "should be willing to test and experiment with new technologies, as well as adapt new methodologies that we use currently in the constant search for educational excellence” (De Haro, 2009: p. 91).

In Section 2, this paper presents the Kelluwen Projetc and study method. In Section 3, we work results and discussion of chilean teachers experiences. Specifically, in 3.1 we explain Youtube experiences and 3.2 we describe Gigapan experiences. Finally, in the last section we present the main conclusions of this paper.

\section{Project Kelluwen and Study Method}

Kelluwen is Mapudungun word (native language in Chile) that means "work together" and is the name of the project which outlines these experiences. This initiative developed over 3 years of innovative educational interventions with Social Web in 161 classrooms, and 4517 students participating from primary and secondary publics 
schools in 12 cities in the south of Chile.

The initiative mixed elements of learning based on collaborative learning projects (Palacheewa, Suwannatthachote, \& Nilsook, 2012). With the goal of encouraging synergies within an active school, making more visible the products of the classroom projects in Web 2.0, and developing collaboration dynamics between the students. Kelluwen promoted the implementation of 16 Design Didactics (DD). A Didactic design is the planning of a unit scholar contents in Language or History. Every DD connect times, contents and activities in the learning process (Cárcamo \& Troncoso, 2013). Specifically, these DD involved periods from four to six weeks of classes, paring regular curriculum contents, mediation from Web 2.0 tools and co-evaluation processes between inter-classrooms of different schools. 2 of 16 Design Didactics proposes the production of audiovisual task of learning. These were the cases described in this paper (Table 1).

In the DD "Constructing a diorama of the 20th Century" contemplated the participation of 16 classrooms from secondary schools, and for the case named "I'll tell you my story," 10 classrooms were involved from primary schools. In the first of these initiatives, YouTube was used to publish audiovisuals elaborated by the students. In the second, the students used GigaPan in order to articulate the task of settings of the literary pieces in high-definition photographs.

Study method: The methodology is based on a case study approach (Stake, 1995; Yin, 1994; Yuen, Law, \& Wong, 2003). The ethnography is build around the teacher's interviews (Ogbu, 1981) and field notes from investigators that participated in the executed DDs. The study questions which guided our reflections were:

1) Do the teachers have favorable, negative or mixed perceptions on the educative innovation with Gigapan or YouTube?

2) Do the teachers have favorable, negative or mixed perceptions on the collaborative work and co-evaluation in your classrooms?

This study is based on teachers perspectives (Concannon, Brown, \& Brown, 2013). To incorporate the social web in education depend of to break traditional strategies in teaching.

Participants: 1) Teachers chosen for the study are from primary and secondary public schools which have participated in Kelluwen Project. 26 teachers were involved in this study, from 25 and 45 year old, 14 women and 12 men. Teachers average age is 34.5 years. 2) Transference researchers are teachers and postgrade student, from 24 to 27 years old. The average age for transference researchers is 25 years. They are women teachers of social sciences and language and advanced users in ICT.

Data gathering: The data were obtained from:

1) Reports and observational notes of researcher in situ every week. Four transference researchers wrote reports based on observational notes and planning meetings. Every week visit to teachers and classrooms one time. The researcher helped to teachers, resolved technical questions and observed work in computational laboratories.

2) Teacher's autoreport. At the end of the transference process, every teacher wrote an autoreport for evaluating their classroom, analyzing the innovation, the collaborative work, reception of the students and audiovisual evidence of learning.

3) In-depth interviews to teachers. Each interview lasted between 25 to 30 minutes. All interviews were semi structured, with consent from the respondents, all the discussions and interviews were audio recorded.

The data language is Spanish. Whenever data transcripts are relevant to support analysis presentation, an English version of them will be provided.

Analysis: The large number of classrooms and teachers considered here made it possible to apply a qualitative approach to the data. Transcripts were organized in software (QDA-Miner) that preserved details of speaker gender, school and year group.

Table 1. Pilotage and validation of didactic designs.

\begin{tabular}{cccc}
\hline Didactic designs (DD) & \multicolumn{2}{c}{ Classroom } & \multicolumn{2}{c}{ Totals } & 2011 & 2012 \\
\cline { 2 - 3 } Building a diorama of the 20th Century History and Social science/Secondary & 5 & 3 & 5 \\
I'll tell you my story Language and Communication /Primary & - & 5 & 16 \\
Totals & 5 & 10 & 26 \\
\hline
\end{tabular}


Sections of the conversations were identified that concerned participants orientation to technology and the Web 2.0 within school. For qualitative analysis, a Grounded Theory approach towards extracting perspectives on these themes was adopted

\section{Results and Discussion}

In 3 years of Kelluwen Project participated 57 schools of 17 municipalities (councils) in 3 regions (states) of Chile. Every experience lasted 4 to 6 classroom's weeks. In general, 33 classrooms didn't achieve to work $70 \%$ of activities, others 33 achieved between $70 \%$ and $99 \%$. Finally, 95 classrooms achieved all activities proposed in the innovation (Kelluwen Project).

Specifically, in "Constructing a diorama of the 20th Century" (Classrooms A) and "I'll tell you my story" (Classrooms B), three classrooms didn't achieved to do $70 \%$ of activities, others three achieved between $70 \%$ and 99\% and, finally, 20 classrooms achieved to finish all activities (Figure 1).

\subsection{Using YouTube for the Critical Expression of History}

"Constructing a diorama of the 20th Century" was conceived in the year 2010 with the objective that the teachers, supported by a general vision of the history of the 20th century, could propose a discussion about historical milestones that generated human catastrophes, which today leave a hard lesson about human rights violations.

The work with the professors permitted the installation of a proposal that resulted attractive for the students, given the familiarization with the audiovisual narratives (Figure 2). On occasions, the technical expertise of the professors allowed them to incorporate enriching modifications to the DD. In this manner, such as in the Liceo of Quellón (Quellón School), the professor proposed the use of a software called aTubeCatcher to download audiovisual segments from the Internet, with the goal of enhancing the production work of messages with transmedia sense.

"The program aTubeCatcher was used in the activity 'The 20th Century through images'. During the first half of the development phase, the students used the program to download from the web videos that had information about the topics that each group was executing: the decolonization of India, the anti-nuclear movement, among others. This alternative was proposed by the professor to improve the construction of the videos in the DD 'Constructing a diorama of the 20th Century'.” Transference researchers in the School Liceo Rayén Mapu of Quellón.

Of course the potential of "Constructing a diorama of the 20th Century", did not reside only in the technical-practical dimensions of the didactic task, but also in the empowerment of the students as opinionated subjects regarding history and their environment. The revision of the historical milestones related to the economic depression of the 1930s, or the industrialization of the Oriental world gave place for the creation of audiovisuals related to working-class poverty and child labor. Debates were also sparked about the World Wars.

"This experience permitted me to grow as a teacher: it showed me how to create significant learning instances, giving spaces for reflexion, debate, and above all, harmony among the students and group work based on a clear objective. My students, through what they have manifested in their journals, as well as personally in direct form to me, have demonstrated their enthusiasm and willingness to keep working with the Web 2.0 tools. The students have recognized that they have a great opportunity to learn and grow as students and people that daily must face society.” Professor from a classroom at the Escuela Hospilitaria of Osorno.

The participating professors pointed out that it was very important that work with human rights was able to be carried out, given that the students saw how vulnerable they were on a daily basis. Also, upon working with the Kelluwen methodology, the professors could observe as students from other regions embarked on the same experiences as their peers. The dialogic learning processes are added, in the majority of the DD, though the co-evaluation of the learning evidence from sister classrooms (Figure 3), or from the tasks from the same classroom, with the objective of making the students participate in processes that normally remain reduced to teacher criterion.

"The sister classrooms, as a possibility for evaluating the work of other groups, and at the same time to be evaluated by other schools doing the same co-evaluation and auto-evaluation processes, is more than interesting, given that in schools the traditional methods of evaluations are prioritized (...). With the proposal from Kelluwen, the students were put in charge of their opinions and their criticism, having the possibility to participate in an evaluation."-Professor from a classroom in the Colegio Austral of Valdivia. 


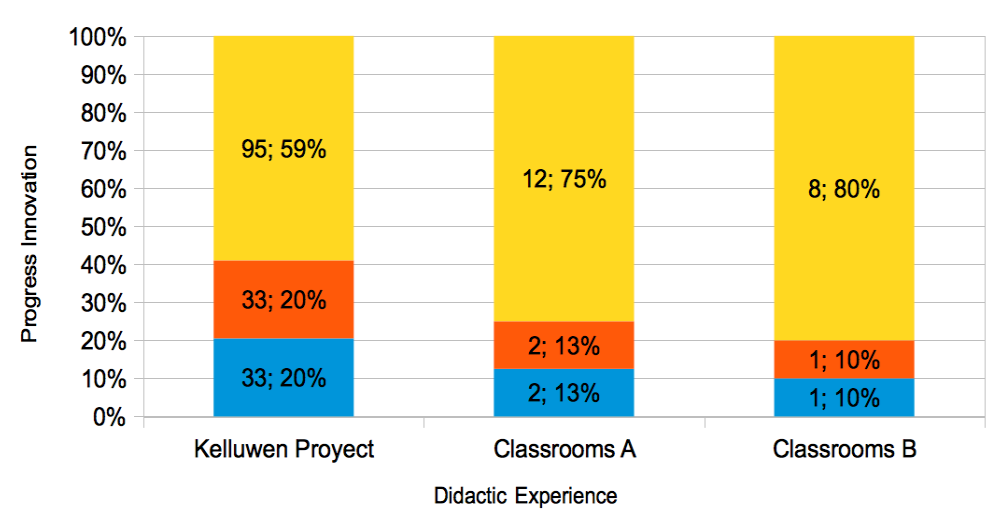

"Insufficient progress, $<70 \%$ —ood progress, $>70 \& 99 \%$ Successful progress, $100 \%$

Figure 1. Degree of implementation in Kelluwen Project.

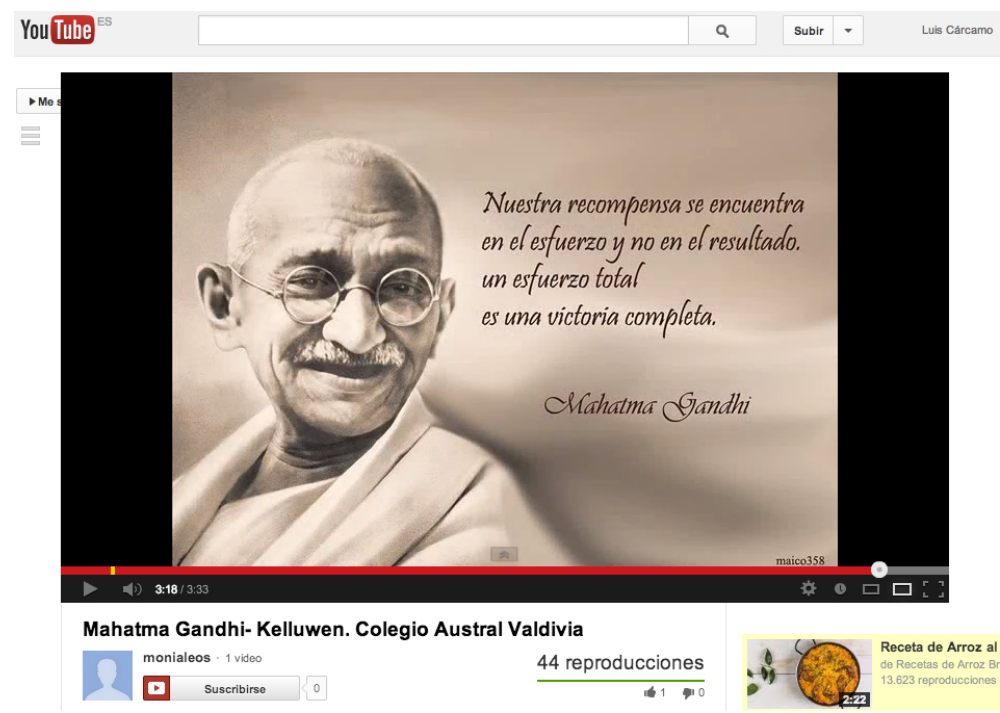

Figure 2. Capture of learning evidences, videos uploaded by the students.

\subsection{Gigapan: Recreating Literature with High-Definition Photos}

The experiences from the DD "I'll tell you my story" proposed an active approach to the literary works suggested by the scholarly curriculum. In the year 2011, the contact with the Carnegie Mellon University, made access to equipment possible which robotized the photo capture of panoramic scenes in high-definition with GigaPan.

The project GigaPan Youth Exchange combined cultural uncertainties, photo technology and social web, allowing students to share their school culture from the south of Chile. The experiences of the professors from primary schools from Valdivia and Puerto Varas, highlighted the value of technological novelty, and the organization of the work in groups overcoming technical difficulties.

"Kelluwen is more didactic, and the students can learn, doing it themselves, as well as looking for and selecting information by themselves. In this sense, I think it is much more entertaining for the student, the teacher links them to learning in a fun way, such as a game, and the students see it that way." Professor from Escuela Mexico of Valdivia

The investigation aimed to make GigaPan equipment available for the tasks carried out by students from primary school (7th and 8th grades). To do this, a didactic strategy was proposed that would permit the revitalization of literature acquisition processes. This was realized through an initiative of the active school that combined traditional literature, performativity and the audiovisual register online.

GigaPan is a technology that resulted completely unknown by the teachers that participated in the learning ini- 


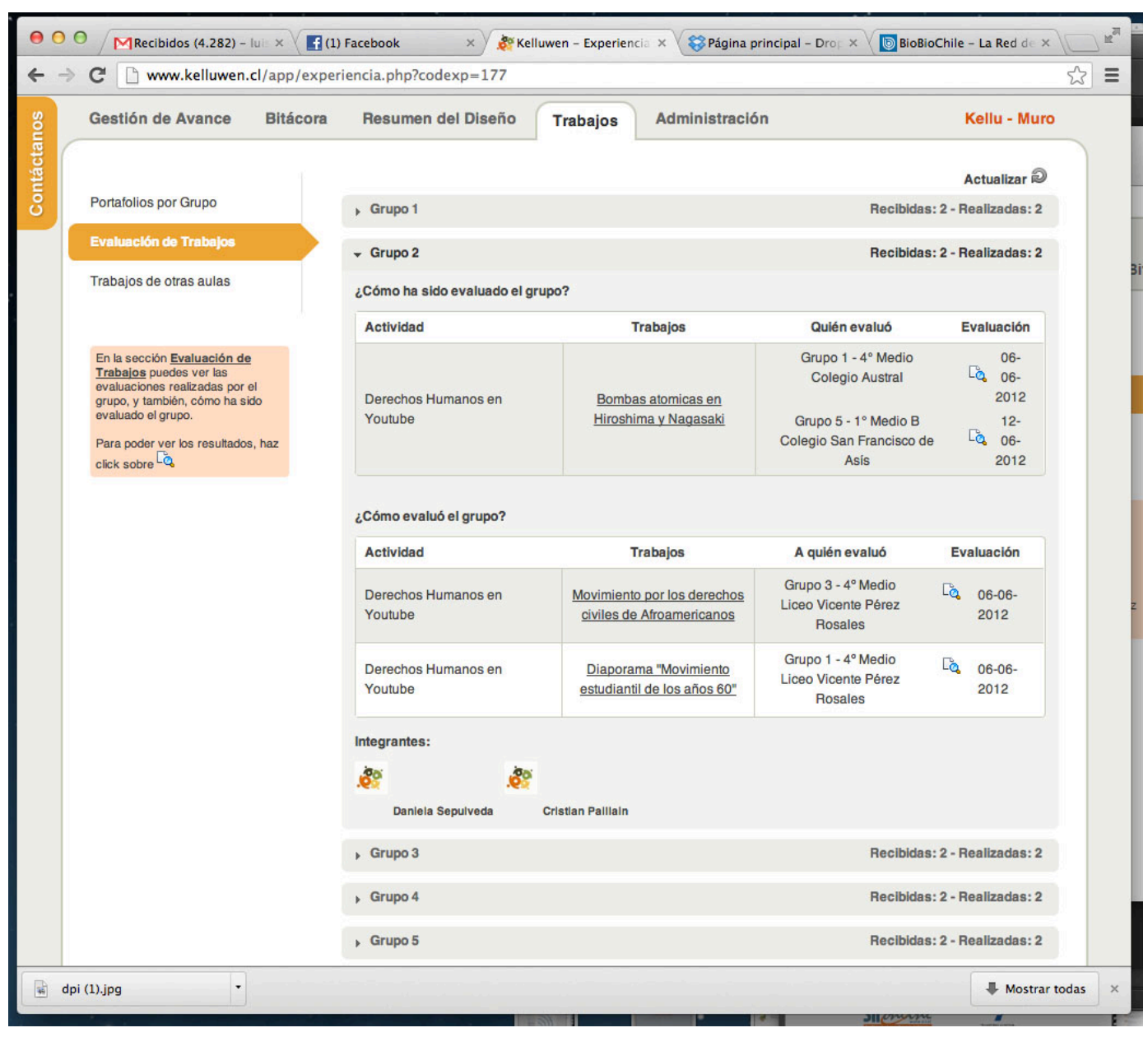

Figure 3. Co-evaluation window of the works carried out in Kelluwen.

tiatives based on the project. It is for this reason that the on-site group tasks for the Kelluwen team implicated a strategy of technological training that permitted the appropriation by the professor and the course group. It was very important to avoid that the innovation was transformed into a stumbling block that led to the abandonment of the DD.

The design "I'll tell you my story" was centered in reading, analysis and representation of a story in groups of six students. The group work was executed in base of reading comprehension and literary analysis of stories with respect to the narrators, characters and spaces that a narrative story can present. In parallel to the curricular requirement, the students had the possibility to learn about the functionalities of the Web 2.0 tools-take photos with GigaPan and share them with sister classrooms. This articulation generated a great expectation within the students.

"The enthusiasm was seen at the beginning of every class, they asked me all the time, 'are we going to go to the computer lab?' The fact that they worked exclusively on what they had to work on, and not look at other pages (....), generally this distraction is present. You bring them to the computer lab and immediately its Facebook or other pages that they visit. With Kelluwen, they concentrated amazingly on their work, respected the time limits, and were very enthusiastic. They had many expectations, and they themselves set forth goals and became preoccupied with completing them.” Professor, Escuela México of Valdivia.

For this DD, the groups centered on their work in the representation of a scene of a previously analyzed story. In this way, the students shared their visions of the literary text with the sister classrooms through the tool www.gigapan.org and support from the robot GigaPan. Finally, the students gave feedback on the activities of the other students and evaluated their own personal work.

"The principal use of the educational platform gigapan.org was destined to the publication, valorization and feedback on the processes elaborated by each work group and sister classroom. The students achieved the initial 
management of the platform, being able to recognize elements of literary analysis, comment, and give feedback using "hash tags" in the scenes of the stories represented." Transference researcher, talking about experiences from the Escuela México, Valdivia.

It is important to note that the technological appropriation should contemplate the differences in each school's context. For example, while in the school in Valdivia, the professor worked with a large group of students, (32), in the Rural School of Puerto Varas, there were only 11 students. From a technological training standpoint, the contexts were dissimilar, especially in the Rural School, where most of the students were setting up email accounts for the first time. In Valdivia, most of the students already had email or Facebook accounts which they used habitually.

The extracurricular progress that the present DD showed, had to do with the protagonism and autonomy that the students acquired during the execution of the design, which let them work in a active and enthusiastic manner in order to obtain a quality scholarly product (Figure 4). Upon taking responsibility for their own teaching-learning processes, the students showed interest in the acquisition of knowledge.

"Once the generic aspects of the story were assimilated, the professor oriented each group of students, paying attention to the details of the story to complete a planning worksheet of the photo session. The students selected a scene from the story to represent, and in the workbook, they detailed aspects such as: locations, characters, scenes, and the wardrobe necessary to mount the representation. During the week, they obtained the artifacts for the creation of their scene." Transference researcher, from the experience in the Rural School Horizonte of Puerto Varas.

GigaPan, as a tool applied to the development of literary interpretation and group work skills, was transformed into a motivational motor for the collaboration dynamics that were demanded from the DD. In this manner, the collaborative didactic activities, with ITC integration, resulted to be functional for the sequence of the expected learning objectives. In the time that was dedicated to the formal curriculum, the students also developed technological competencies, a group work culture and even in the affective relationships between the students and the teachers.

"The positive value places on the teacher was evidenced as much by the sense of confidence generated by Kelluwen, as the ITC competencies, management and appropriation of the DD, use of the Kelluwen platform to

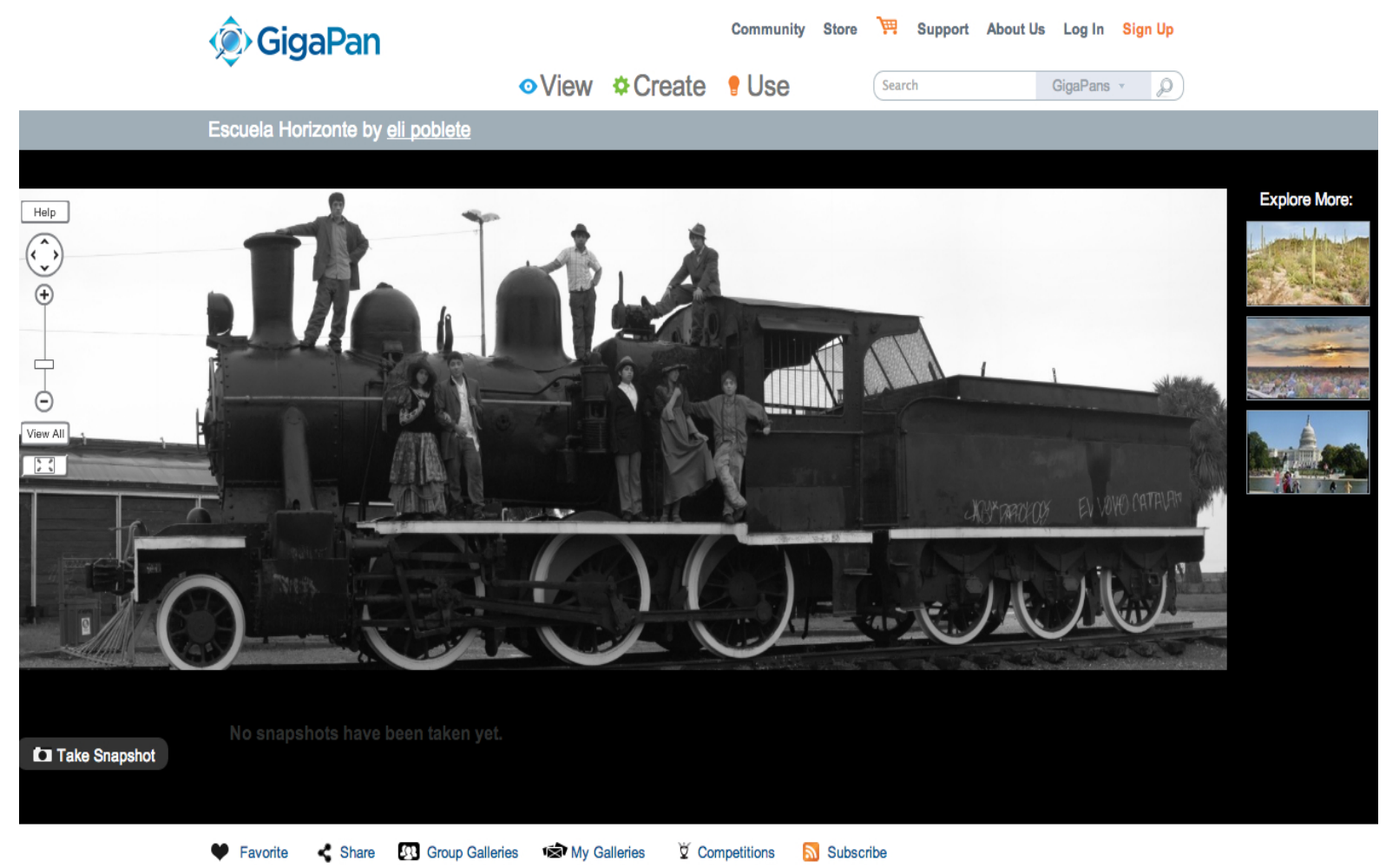

Figure 4. Picture experience with Gigapan. Rural school Horizonte de Puerto Varas. 
interact and set out agendas for the students the willingness for change, autonomy, problem resolution and the capacity to adequately guide the didactic sessions, upon controlling the variables presented." Transference researcher about the experience in the Escuela México of Valdivia.

\section{Conclusions}

The evidences of data gathering propose a positive teacher's perceptions front the ICT. The achieves in "Constructing a diorama of the 20th Century" and "I'll tell you my story" more than general achieves in Kelluwen project.

The experiences contemplate students very willing to adapt to the use of ITCs for learning. The professors perceive and value the motivation of the students by the student's use of the technologies, the learning based on projects, the interest in using Web 2.0 and its potential for interaction in collaborative learning. This situation is implemented through the innovation of Internet resources (De Haro, 2009), but achieves real development in the context of collaborative work, and the production of learning evidences.

Equal to the experiences shown by Ivala et al. (2013) in university contexts, the creation of audiovisual narratives can be a didactic practice that is successful in schools. Also, the students have sufficient tools to construct stories about curricular contents that normally are approached based on traditional reading-writing dynamics.

The co-evaluation by peers though Web 2.0 technologies opens a plethora of possibilities for the creation of didactics using collaboration and of the investigation of interactive learning dynamics, overcoming the traditional behaviorist outlines that still inhabit schools (Crook, 2012). The professors value aspects role planning and interactions based on collaboration, for the success of a common objective that can be provided by didactics from the project Kelluwen. This project proposes that the creative uses of tools such as YouTube and GigaPan in scholarly contexts pass through the incorporation of dialogic, communicative interactions that are more than informational, as has been shown (Cladellas et al., 2011).

\section{Difficulties and Limitations}

To finish this article, is important to make a critical reading of the difficulties in situ:

1) The Chilean educative system implies standardized evaluation for all schools. These tests are applied to all the students, and schools are ranked by the students results. Hence, public schools focus on prepare their students to answer this test but not very successfully. The final effect is promoting private education with public funding. These standarized tests push the schools to the definition of specific training dynamics, but not to the innovation and creativity

2) The innovations didactics fight against tradition. The teacher select traditional practices in order to save time. Innovation, becomes more difficult considering the time constrains, in a country where school teachers, spend more than 32 hours per week in a classroom, having a small amount of time to develop an innovation.

Finally, is important remark that we think that it is a mistake to consider the use of ITCs as an ultimate goal. The goal is to improve the learning process, and ITCs are just tools for this purpose. In our perspective, the right way is to design dynamics that-using ITCs tools-promotes values and abilities, like pro-activity, leadership, and creativity in the classroom. In that sense, the success of the Kelluwen project can be explained due the teachers compromise. They implemented constantly improving of the educational practices in the schools.

\section{Acknowledgements}

The authors would like to thank the Chilean Fondef-Conicyt Grant that supported the investigation D08I1074: "Kelluwen: Research, development and validation of collaborative didactic designs supported by Web 2.0." It is also necessary to thank the Gigapan Youth Exchange project, that together with the Carnegie Mellon University which facilitated the technology used in the project. Scientific Management: Research and Development Direction UACh (Universidad Austral de Chile).

\section{References}

Astigarraga, E., Azpillaga, J., Fernández, L., \& Naberan, A. (2011). Umap, Inteligencia colectiva extraída de las redes sociales. El Profesional de la información, 20, 542-547. http://dx.doi.org/10.3145/epi.2011.sep.08

Cárcamo, L., \& Troncoso, D. (2013). Kelluwen: Un modelo didáctico para el trabajo colaborativo y la inserción curricular de 
las TIC. In L., Cárcamo, E., Scheihing, \& Cárdenas, C. (Eds.), Didáctica 2.0. La Web Social en el aula (pp. 53-65). Valdivia: Ediciones Kelluwen.

Cladellas, R., Cárcamo, L., \& Castelló, A. (2011). Motivación y etimación del tiempo en el uso de herramientas internet informacionales y dialógicas. El Profesional de la información, 20, 25-31. http://dx.doi.org/10.3145/epi.2011.ene.03

Concannon, J., Brown, P., \& Brown, E. (2013). Prospective Teachers’ Perceptions of Science Theories: An Action Research Study. Creative Education, 4, 82-88. http://dx.doi.org/10.4236/ce.2013.41011

Crook, Ch. (2012). The "Digital Native” in Context: Tensions Associated with Importing Web 2.0 Practices into the School Setting. Oxford Review of Education, 38, 63-80. http://dx.doi.org/10.1080/03054985.2011.577946

De Haro, J. (2009). Algunas experiencias de innovación educativa. ARBOR: Ciencia, Pensamiento y Cultura, 185, 71-92. http://dx.doi.org/10.3989/arbor.2009.extran1207

Gao, F., Luo, T., \& Zhang, K. (2012). Tweeting for Learning: A Critical Analysis of Research on Microblogging in Education Published in 2008-2011. British Journal of Educational Technology, 43, 783-801. http://dx.doi.org/10.1111/j.1467-8535.2012.01357.x

Florentín, P., Satisteguí, P., Herrando, I., \& Tobajas, J. (2011). Promoción de la salud a través de herramientas web 2.0. Proyecto de colaboración entre universidad y enseñanzas medias. ARBOR: Ciencia, Pensamiento y Cultura, 187, $165-169$. http://dx.doi.org/10.3989/arbor.2011.Extra-3n3139

Giannakos, M., \& Vlamos, P. (2013). Educational Webcasts’ Acceptance: Empirical Examination and the Role of Experience. British Journal of Educational Technology, 44, 125-143. http://dx.doi.org/10.1111/j.1467-8535.2011.01279.x

Ivala, E., Gachago, D., Condy, J., \& Chigona, A. (2013). Enhancing Student Engagement with Their Studies: A Digital Storytelling Approach. Creative Education, 4, 82-89. http://dx.doi.org/10.4236/ce.2013.410A012

Lint, A. (2013). E-Learning Student Perceptions on Scholarly Persistence in the 21st Century with Social Media in Higher Education. Creative Education, 4, 718-725. http://dx.doi.org/10.4236/ce.2013.411102

Mardones, D., \& Cárcamo, L. (2013). Nativos digitales en el sur de Chile. El caso del establecimiento María Alvarado Garay en la comuna de Panguipulli. OBS* Journal, 7, 001-019. http://obs.obercom.pt/index.php/obs/article/view/637/581

Mineduc (2011) Programas de Estudios para Lenguaje y Comunicación. Ministerio de Educación de Chile. http://curriculumenlinea.mineduc.cl/

Ogbu, J. (1981). School Ethnography: A Multilevel Approach. Anthropology \& Education Quarterly, 12, 3-29. http://dx.doi.org/10.1525/aeq.1981.12.1.05x1281g

Palacheewa, P., Suwannatthachote, P., \& Nilsook, P. (2012). Critical Issues to Be Concern in Selecting Tools for Teaching High School Computer Project Lesson Using Computer-Supported Collaborative Learning. Creative Education, 3, 11-14. http://dx.doi.org/10.4236/ce.2012.38B003

Pimmer, C., Linxen, S., \& Gröhbiel, U. (2012). Facebook as a Learning Tool? A Case Study on the Appropriation of Social Network Sites from Mobile Phones in Developing Countries. British Journal of Educational Technology, 43, 726-738. http://dx.doi.org/10.1111/j.1467-8535.2012.01351.x

Schoen, J., \& Stevenson, R. D. (2010). Uses of Gigapan Technology in Formal and Informal Environmental Education. Fine International Conference on Gigapixel Imaging for Science. Paper 10. http://repository.cmu.edu/gigapixel/10

Stake, R. E. (1995). The Art of Case Study Research. Thousand Oaks, Sage Publications

Wang, M., Shen, R., Novak, D., \& Pan, X. (2009). The Impact of Mobile Learning on Students’ Learning Behaviours and Performance: Report from a Large Blended Classroom. British Journal of Educational Technology, 40, 673-695. http://dx.doi.org/10.1111/j.1467-8535.2008.00846.x

Yin, R. K. (1994). Case Study Research: Design and Methods. Thousand Oaks, CA: Sage.

Yuen, A. H. K., Law, N., \& Wong, K. C. (2003). ICT Imple Mentation and School Leadership: Case Studies of ICT Integration in Teaching and Learning. Journal of Educational Administration, 41, 158-170.

http://dx.doi.org/10.1108/09578230310464666 
Scientific Research Publishing (SCIRP) is one of the largest Open Access journal publishers. It is currently publishing more than 200 open access, online, peer-reviewed journals covering a wide range of academic disciplines. SCIRP serves the worldwide academic communities and contributes to the progress and application of science with its publication.

Other selected journals from SCIRP are listed as below. Submit your manuscript to us via either submit@scirp.org or Online Submission Portal.
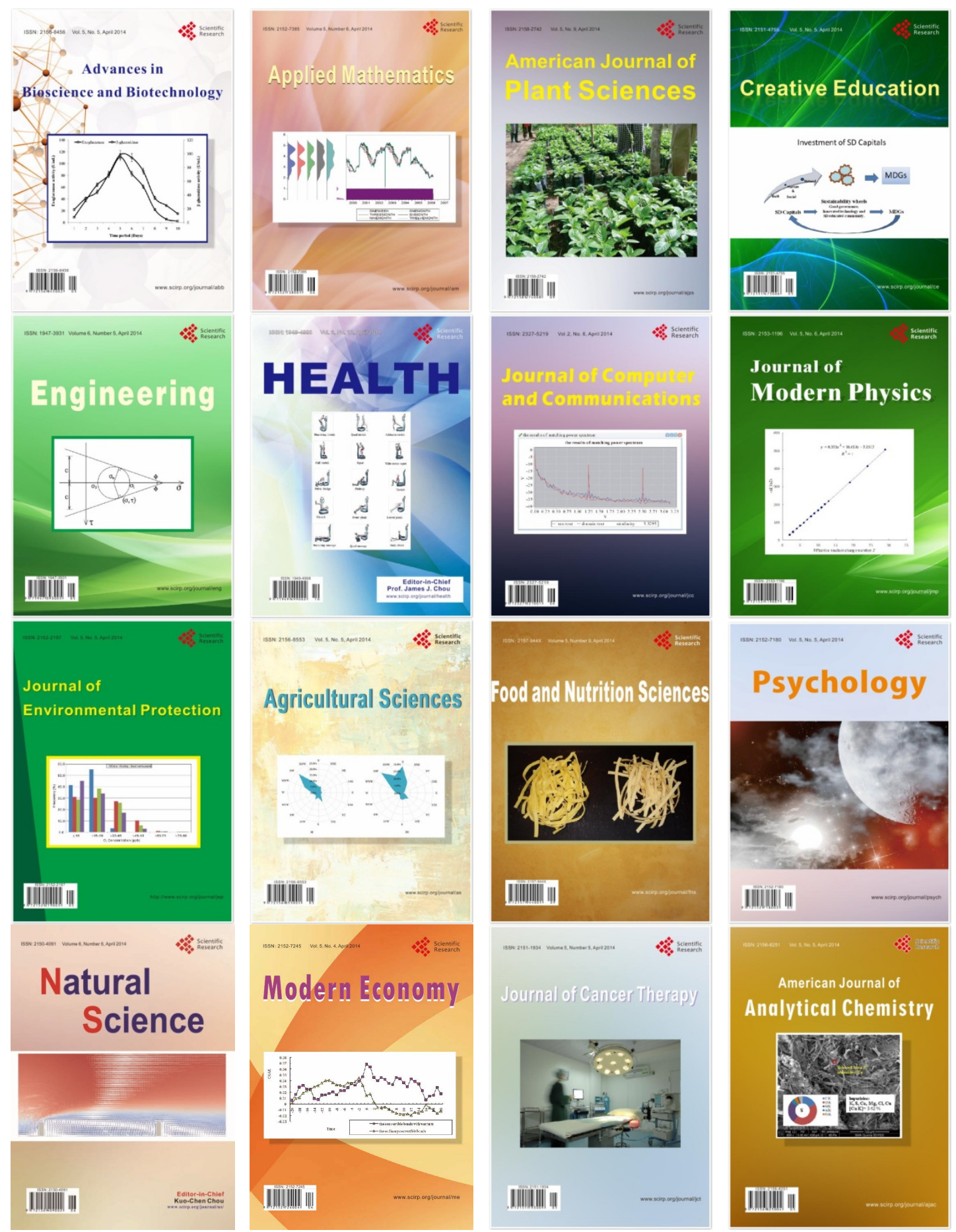